\title{
IgG ANTIBODY RESPONSES IN MICE COINFECTED WITH Toxocara canis AND OTHER HELMINTHS OR PROTOZOAN PARASITES
}

Susana A. Zevallos LESCANO(1), Maria Cristina NAKHLE(1), Manoel Carlos S.A. RIBEIRO(2) \& Pedro Paulo CHIEFFI(1,2)

\begin{abstract}
SUMMARY
The immune response expressed by $\operatorname{IgG}$ antibodies in BALB/c mice experimentally infected with Toxocara canis, was studied with the aim of verifying the possible in vivo cross-reactivity between antigens of T. canis and other parasites (Ascaris suum, Taenia crassiceps, Schistosoma mansoni, Strongyloides venezuelensis and Toxoplasma gondii). Experiments included three groups of mice: one infected only by T. canis, another with one of the other species of parasites and a third concomitantly infected with T. canis and the other species in question. Animals were bled by orbital plexus at 23, 38 and 70 days post infection (p.i.). Sera were analyzed for anti-Toxocara antibodies by ELISA and Immunoblotting, using excretion-secretion antigens (ES), obtained from culture of thirdstage larvae of $T$. canis. For all experiments a control group comprised by ten non-infected mice was used. Only in the case of $A$. suum infection, in these experimental conditions, the occurrence of cross-reactivity with $T$. canis was observed. However, in the case of co-infection of T. canis - S. mansoni, T. canis - S. venezuelensis and T. canis - T. crassiceps the production of anti-Toxocara antibodies was found at levels significantly lower than those found in mice infected with T. canis only. Co-infection with S. mansoni or S. venezuelensis showed lower mortality rates compared to what occurred in the animals with single infections. Results obtained in mice infected with T. canis and T. gondii showed significant differences between the mean levels of the optical densities of animals infected with $T$. canis and concomitantly infected with the protozoan only in the $23^{\text {rd }}$ day p.i.
\end{abstract}

KEYWORDS: Toxocara canis; Ascaris suum; Taenia crassiceps; Schistosoma mansoni; Strongyloides venezuelensis; Toxoplasma gondii; Coinfection; IgG; Humoral response.

\section{INTRODUCTION}

In natural conditions host susceptibility to infection by several species of parasites may be subjected to pressures resulting in multiple infections that should manifest differently to the simple summation of individual effects of each infection. Such concomitant factors of injury should always be considered, despite being often overlooked in clinical practice.

From the experimental point of view and also under a theoretical perspective, there are several studies on the interactions among parasites harbored by the same host reporting either competitive action, development of cross-immunity, synergy or indifferent coexistence ${ }^{7,28}$. In certain circumstances, changes that take place among organisms of different species that live as parasites on the same host manifest negative interactions increasing the immune response against a second parasite by means of cross-immunity or, conversely, cause immunosuppression of the host, thus showing a positive interaction ${ }^{10}$.

Helminth parasites can live in their hosts for long periods; for this to happen either the host immune system must be depressed or the invading agent has to own some adaptations conferring resilience to the attacks of the host immune response. In the case of $T$. canis larvae that induce strong eosinophilic inflammation they seem to be refractory to this reaction, allowing the parasite to survive in different host species, for several years ${ }^{4}$.

The murine models of helminthic infections have become very important to identify the protective mechanisms mediated by antibodies and specific immune-effector cells that also contribute to protective immunity. Experiments with mice have provided data indicating that antibodies, particularly IgG and $\operatorname{IgM}$, can act as potent mediators of protective immunity after infection with helminth parasites ${ }^{22}$.

Since mice mimic well human toxocariasis, tolerating massive infections for long periods without suffering significative changes they are adequate hosts for studying this disease. This rodent may also be infected with other helminthic and protozoan parasites facilitating the study of concomitant infections ${ }^{6,20}$.

In the present paper the humoral response in mice infected only by

\footnotetext{
1. Instituto de Medicina Tropical de São Paulo (LIM 06) da Universidade de São Paulo. São Paulo, SP, Brazil.

2. Faculdade de Ciências Médicas da Santa Casa de São Paulo, São Paulo, SP, Brazil.

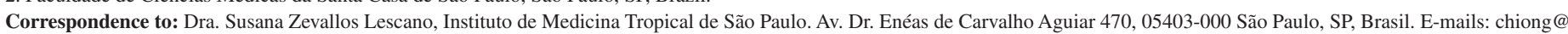
uol.com.br, pchieffi@usp.br
} 


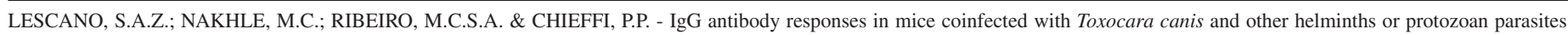
Rev. Inst. Med. Trop. Sao Paulo, 54(3): 145-52, 2012.

Toxocara canis and coinfected by one of other parasites (Ascaris suum, Taenia crassiceps, Schistosoma mansoni, Strongyloides venezuelensis or Toxoplasma gondii) was studied in order to understand the dynamics of host-parasite relationships in concomitant infections.

\section{MATERIALS AND METHODS}

Infection of animals: One hundred and thirty BALB/c male mice, five to six weeks old, were divided into three groups, each one infected by one species of helminth or protozoan parasite or concomitantly with T. canis, according to the scheme indicated in Table 1. The last group, composed of 10 mice free of infection, was used as control.

Parasites: Females of $T$. canis were dissected to obtain eggs maintained in formaldehyde solution $2 \%$, at least for 30 days at $28^{\circ} \mathrm{C}$, with periodic oxygenation, to achieve infective larvae. Adults of $A$. suum were obtained from pigs slaughtered in the Itapecerica da Serra city abattoir, and females were also dissected and the eggs kept in the same way that those of T. canis for obtaining infective eggs. Cysticerci of $T$. crassiceps were provided by the Faculty of Pharmaceutical Sciences, USP, obtained after the sacrifice of experimentally infected mice. Cercariae of $S$. mansoni were obtained in the Laboratory of Immunopathology of Schistosomiasis of the Instituto de Medicina Tropical de São Paulo (IMT), after exposure of Biomphalaria glabrata experimentally infected to artificial light for 60 minutes. Infective larvae of $S$. venezuelensis, obtained from experimentally infected mice, were provided by the Parasitology Service of the Adolfo Lutz Institute. The cystogenic ME49 strain of T. gondii was provided by the Department of Parasitology, University of Campinas (SP) and maintained in BALB/c mice in the Laboratory of Immunopathology of Schistosomiasis of the IMT. The cysts were obtained from homogenization of the central nervous system of infected mice.

All animals used in the experiments were previously treated with Mebendazole to prevent interference from unwanted infections.
Parasitological examinations: The infection of each batch of mice with different species of parasites was proved as follows:

- Schistosoma mansoni, finding of eggs in stool tests by spontaneous sedimentation and hatching of miracidia from the $50^{\text {th }}$ day after infection.

- Strongyloides venezuelensis, presence of eggs or larvae in the feces of the fourth to seventh day post-infection (pi).

- Taenia crassiceps, ascites formation from the $30^{\text {th }}$ day p.i.

- Toxoplasma gondii, cysts formed in brain examined at the end of the experiment.

- Ascaris lumbricoides, larval recovery from tissues at the end of the experiment.

- Toxocara canis, larval recovery from tissues at the end of the experiment.

Sera collection: The three animal groups were anesthetized, with xylazine and ketamine, and bled by orbital plexus puncture at 23,38 and 70 days after infection. All sera were frozen and stored at $-20{ }^{\circ} \mathrm{C}$ in aliquots in plastic micro tubes, for subsequent processing by ELISA and Immunoblotting.

T. canis ES antigen: The excretion-secretion antigen (ES) of $T$. canis was prepared in the Laboratory of Seroepidemiology of IMT, from the culture of infective larvae of this parasite in Eagle medium, according to a standardized technique by Bach-Rizzatti ${ }^{3}$ and modified in this laboratory. The protein concentration of the antigen, determined by the method of LOWRY et al. ${ }^{29}$, was $600 \mu \mathrm{g} / \mathrm{mL}$. Protease inhibitor (PMSF: Phenylmethylsulfonil Fluoride) $200 \mathrm{mM}$ at a concentration of $5 \mu \mathrm{L} / \mathrm{mL}$ of antigen was added to the antigen thus obtained which was then stored in aliquots at $-20{ }^{\circ} \mathrm{C}$ until use.

Enzyme-linked immunosorbent assay (IgG ELISA): All serum samples collected from animals with single or concomitant infections were examined by ELISA to detect anti-Toxocara antibodies. Different concentrations of ES antigen of T. canis were tested using positive and

Table 1

Schedule of mice infection according to parasite species, inoculum and way of infection

\begin{tabular}{|c|c|c|c|c|}
\hline & $\mathrm{N}^{\circ}$ of Animals & Parasites & Inoculum /animal & Inoculation route \\
\hline \multirow{6}{*}{ Group 1} & 10 & Toxocara canis & 200 eggs & Oral \\
\hline & 10 & Ascaris suum & 200 eggs & Oral \\
\hline & 10 & Schistosoma mansoni & 60 cercariae & Subcutaneous \\
\hline & 10 & Strongyloides venezuelensis & 1,000 larvae & Subcutaneous \\
\hline & $15^{*}$ & Taenia crassiceps & 10 cysticerci & Intraperitoneal \\
\hline & 10 & Toxoplasma gondii & 1 cyst & Intraperitoneal \\
\hline \multirow{5}{*}{ Group 2} & 10 & T. canis + A. suum & 200 eggs each & Oral \\
\hline & 10 & T. canis $+S$. mansoni & 200 eggs +60 cercariae & Oral/ Subcutaneous \\
\hline & 10 & T. canis + S.venezuelensis & 200 eggs $+1,000$ larvae & Oral/ Subcutaneous \\
\hline & $15^{*}$ & T. canis $+T$. crassiceps & 200 eggs +10 cysticerci & Oral /intraperitoneal \\
\hline & 10 & T. canis $+T$. gondii & 200 eggs +1 cyst & Oral/intraperitoneal \\
\hline
\end{tabular}

* Female mice were used in these groups as they were the best hosts for infection. 
LESCANO, S.A.Z.; NAKHLE, M.C.; RIBEIRO, M.C.S.A. \& CHIEFFI, P.P. - IgG antibody responses in mice coinfected with Toxocara canis and other helminths or protozoan parasites Rev. Inst. Med. Trop. Sao Paulo, 54(3): 145-52, 2012.

negative control sera and the protein concentration of $20 \mu \mathrm{g} / \mathrm{mL}(100$ $\mu \mathrm{L}$ per well in plate) was determined for tests to be performed. The enzyme conjugate anti-mouse IgG labeled with horseradish peroxidase ( $\gamma$-chain specific, Sigma Immunochemicals) was used in 1:1,000 dilution. A mixture of $\mathrm{H}_{2} \mathrm{O}_{2}$ and $\mathrm{O}$-Phenylendiamine (1.2-Benzenediamine) Sigma Chemical Co. [C6 $68 \mathrm{~N} 2.2 \mathrm{HCl}]$ diluted in citrate-phosphate buffer was used as substrate.

Results were evaluated by spectrophotometric reading at a wavelength of $492 \mathrm{~nm}$ in Titertek Multiskan apparatus MCC/340 P version 2.20 (LabSystems, Finland). To calculate the threshold of reactivity ("cut off") the average of optical densities (OD) readings of sera from 10 normal animals was considered, plus two standard deviations. As a positive control serum samples from two mice with 70 days of infection were used and, as a negative control, serum samples from mice bled before infection were used.

\section{Western blott}

Polyacrylamide gel electrophoresis (SDS-PAGE): The protein components of the ES antigen of $T$. canis were separated by electrophoresis on polyacrylamide gel at $10 \%$, containing sodium dodecyl sulphate-reducing conditions, in Mini Protean II (Bio-Rad Labs, Hercules, California, USA) equipment. Molecular weight markers, obtained commercially (Sigma), containing the following proteins: Myosin 205 kD, B-Galactosidase 116 kD, 97.4 kD Phosphorylase B, bovine albumin $66 \mathrm{kD}, 45 \mathrm{kD}$ and Ovalbumin Carbonic anhydrase $29 \mathrm{kD}$, were used as standard references. An aliquot of $200 \mu \mathrm{L}$ of the ES antigen of $T$. canis $(600 \mu \mathrm{g} / \mathrm{mL})$ was added to $50 \mu \mathrm{L}$ of sample buffer, boiled for three minutes and applied to the gel, with standard molecular weight. For each gel a 200 volts current was applied until the tracking dye (Bromophenol Blue) reached its far end.

After electrophoresis, the separated fractions of ES antigen in polyacrylamide gel were electrophoretically transferred to nitrocellulose membranes. The nitrocellulose membranes containing the protein fractions of the ES antigen of T. canis were cut into $4 \mathrm{~mm}$ strips and processed by immunoenzymatic assay according to ANDERTON \& THORPE (1980) ${ }^{1}$, being preceded by the blocking of nonspecific sites with PBS plus 5\% (w/v) skim milk (PBS-milk) for one hour at room temperature while stirring. The strips were then incubated by stirring for one hour with serum samples diluted 1:100 in PBS-milk. After three 10-minute washes with PBS-milk, incubation for one hour under stirring with enzyme conjugate labeled with alkaline phosphatase-specific mouse IgG diluted in PBS-milk at a 1:2,000 ratio followed. Again the strips were washed and were placed in a dark chamber in the presence of the enzyme substrate for alkaline phosphatase, a mixture of Bromo-chloro-indolyl phosphate (BCIP) and nitroblue tetrazolium (NBT) diluted in distilled water. After the appearance of bands (5-10 minutes) the reaction was stopped by transferring the strips to distilled water.

Statistical analysis: Nonparametric tests were used, depending on the experiment. In order to analyze the results of concurrent infections the Mann-Whitney test was used. The analysis of mortality data for the test employed was the chi-square. In all cases a significance level of $95 \%$ was chosen.

\section{RESULTS}

\section{Concomitant infections}

1. Toxocara canis-Ascaris suum: Results of the experiment Toxocara canis + Ascaris suum (Fig. 1) showed a significant difference between the levels of anti-T. canis antibodies in animals infected only by $T$. canis and concomitantly infected with A. suum in the $23^{\text {rd }}$ and $38^{\text {th }}$ day p.i., with production of anti-Toxocara antibodies at higher levels in the coinfected group (significance level of $95 \%$ ). However, at the $70^{\text {th }}$ day p.i., no significant difference in the results was observed in these groups. In mice infected only by $A$. suum no reactions were found in the $23^{\text {rd }}$ and $38^{\text {th }}$ days p.i.. However, at day $70^{\text {th }}$ pi. all sera examined showed D.O. above the threshold of reactivity $($ D.O. $=0.107)$.

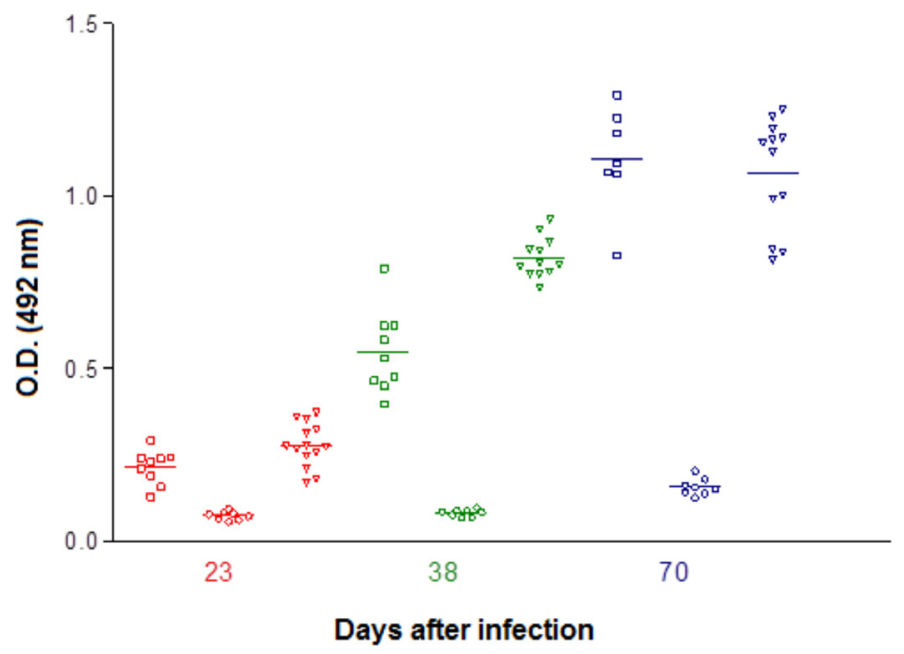

Fig. 1 - Dynamics of ELISA estimated circulating anti- T. canis Ig $\mathrm{G}$ antibodies in BALB/c mice infected with Toxocara canis $(\square)$, Ascaris suum $(\bigcirc)$, and concomitantly $(\nabla)$ with both parasites. Bar represents median.

Western blotting analysis of IgG anti-T. canis revealed that sera from animals infected only by $A$. suum were not reactive, whereas sera from mice infected with $T$. canis and concurrently with both parasites showed similar patterns of reactivity in the $23^{\text {rd }}$ (Fig. 6, strips 1 and 2) and $70^{\text {th }}$ day p.i. (Fig. 8, strips 1 and 2), with a predominance of molecular weight bands of 45 and $97 \mathrm{kDa}$. However, on the $70^{\text {th }}$ day the presence of a band of about $66 \mathrm{kDa}$ was also observed.

Table 2 shows that 70 days after the start of the experiment no significant difference was observed with respect to the lethality in mice in the three groups (isolated infections with T. canis and with A. suum concomitant infection).

2. Toxocara canis-Taenia crassiceps: Figure 2 shows the occurrence of significant differences in the level of anti-Toxocara antibodies revealed by ELISA, from mice infected only by $T$. canis and concomitantly infected with T. canis - T.crassiceps, with higher levels of OD, in animals undergoing isolated infection by $T$. canis in the three occasions that were examined (significance level of $95 \%$ ). Only in mice infected by $T$. crassiceps no reactivity was observed. 
LESCANO, S.A.Z.; NAKHLE, M.C.; RIBEIRO, M.C.S.A. \& CHIEFFI, P.P. - IgG antibody responses in mice coinfected with Toxocara canis and other helminths or protozoan parasites. Rev. Inst. Med. Trop. Sao Paulo, 54(3): 145-52, 2012.

Table 2

Mortality, after 70 days, in BALB/c mice infected by Toxocara canis and in concomitant infection by $T$. canis and other parasites

\begin{tabular}{|c|c|c|}
\hline Infections & No. infected & No. survival \\
\hline Toxocara canis & 10 & 7 \\
\hline Ascaris suum & 10 & 8 \\
\hline T. canis + A. suum $^{(1)}$ & 14 & 12 \\
\hline Taenia crassiceps & 15 & 14 \\
\hline 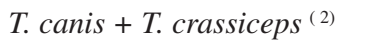 & 15 & 14 \\
\hline Schistosoma mansoni & 12 & 12 \\
\hline T. canis + S.mansoni $^{(3)}$ & 12 & 12 \\
\hline Strongyloides venezuelensis & 10 & 10 \\
\hline T. canis + S. venezuelensis ${ }^{(4)}$ & 10 & 10 \\
\hline Toxoplasma gondii & 10 & 7 \\
\hline T. canis $+T$. gondii $^{(5)}$ & 10 & 5 \\
\hline
\end{tabular}

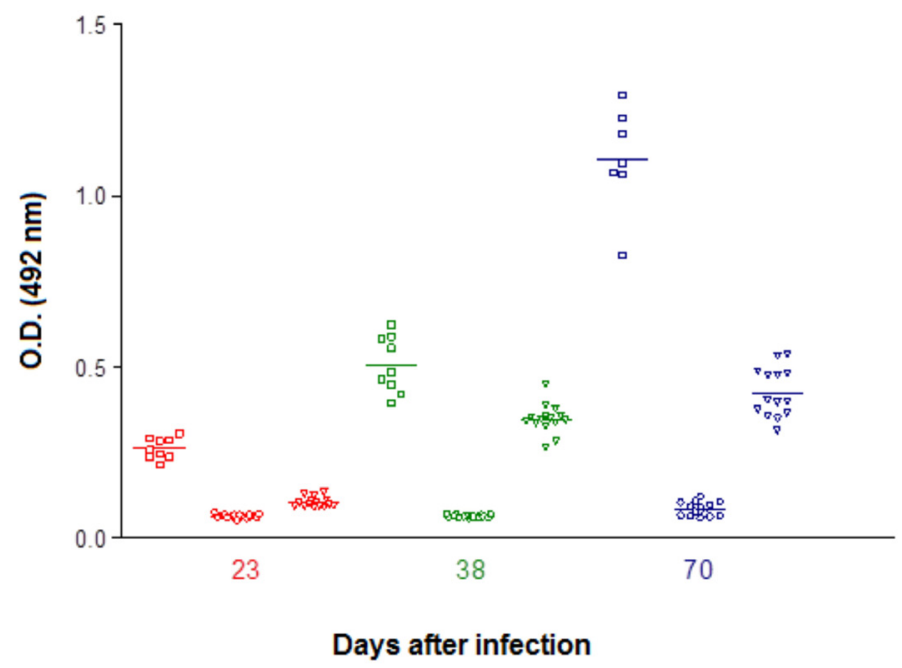

Fig. 2 - Dynamics of ELISA estimated circulating anti- T. canis Ig G antibodies in BALB/c mice infected with Toxocara canis $(\square)$, Taenia crassiceps $(\bigcirc)$, and concomitantly $(\nabla)$ with both parasites. Bar represents median.

Western blotting indicated that sera from mice infected with $T$. canis and concomitantly with $T$. crassiceps showed a similar pattern of reactivity in the $38^{\text {th }}$ (Fig. 7, strips 1 and 3 ) and $70^{\text {th }}$ day p.i. (Fig. 8, strips 1 and 3) with a predominance of $66 \mathrm{kDa}$ and $45 \mathrm{kDa}$ bands; group infected with $T$. crassiceps alone was nonreactive. The results in Table 2 indicate that there was no significant difference $(p>0.05)$ between the rates of mortality in the group infected by $T$. canis, T. crassiceps or concomitantly with both parasites.

3. Toxocara canis - Schistosoma mansoni: Experiment that studied the Toxocara canis + Schistosoma mansoni infections (Fig. 3) showed significant differences between the levels of OD in sera of animals infected with $T$. canis and concomitantly infected with $S$. mansoni in the $23^{\text {rd }}$ and $70^{\text {th }}$ days p.i.. In mice infected only by the ascarid (significance level of $95 \%$ ) higher levels of anti-Toxocara antibodies were noted. The group only infected by the trematode was non-reactive.

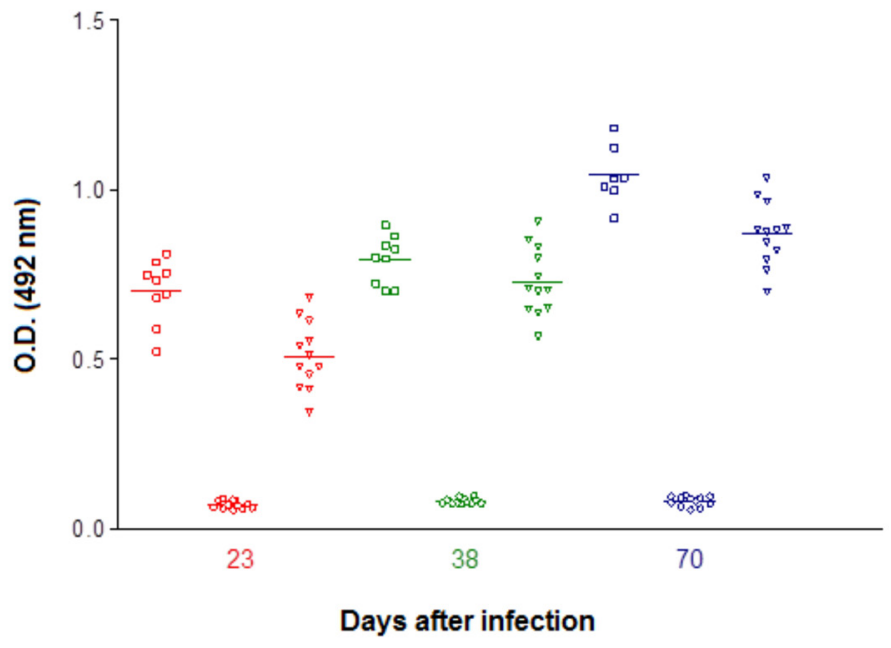

Fig. 3 - Dynamics of ELISA estimated circulating anti- T. canis Ig G antibodies in BALB/c mice infected with Toxocara canis $(\square)$, Schistosoma mansoni $(\bigcirc)$, and concomitantly $(\nabla)$ with both parasites. Bar represents median.

Western blotting of sera from mice infected with these helminths indicated similar patterns of reactivity in the $38^{\text {th }}$ day (Fig. 7, strip 4) and $70^{\text {th }}$ p.i. (Fig. 8, strip 4) with a predominance of bands $97 \mathrm{kDa}$ and $66 \mathrm{kDa}$. The group infected only with $S$. mansoni was non-reactive. Seventy days after the beginning of the experiment a significantly higher mortality in the group of mice infected only by T.canis when compared with the other groups was observed (Table 2).

4. Toxocara canis - Strongyloides venezuelensis: Also in the experiment with $T$. canis + S. venezuelensis (Fig. 4) a significant difference between the levels of OD found in sera of mice infected with $T$. canis and concomitantly infected with $S$. venezuelensis in the three intervals was observed, showing anti-Toxocara antibodies at higher levels in mice infected only with T. canis (significance level of $95 \%$ ). Sera from mice infected only by $S$. venezuelensis were non reactive.

Observing the Western blotting of sera from animals in this experimental group it was noted that the group infected with $S$. venezuelensis was nonreactive; animals infected with $T$. canis and concomitantly with $S$. venezuelensis showed similar reactivity patterns with a predominance of bands of $97 \mathrm{kDa}$. on $23^{\text {rd }}$ p.i. (Fig. 6, strips 1 and 5) and 97, 66 and $45 \mathrm{kDa}$. the $38^{\text {th }}$ day (Fig. 7, strips 1 and 5) and $70^{\text {th }}$ p.i. (Fig. 8, strips 1 and 5). Table 2 shows a significant difference in the mortality rate, with higher levels in mice infected only with T.canis.

5. Toxocara canis - Toxoplasma gondii: The results obtained in mice infected with Toxocara canis- Toxoplasma gondii (Fig. 5) showed significant differences between the levels of OD of animals infected with T. canis and concomitantly infected with the protozoan only on the $23^{\text {rd }}$ day p.i. (significance level of $95 \%$ ). Animals infected only by $T$. gondii were non-reactive in the three intervals of infection. 


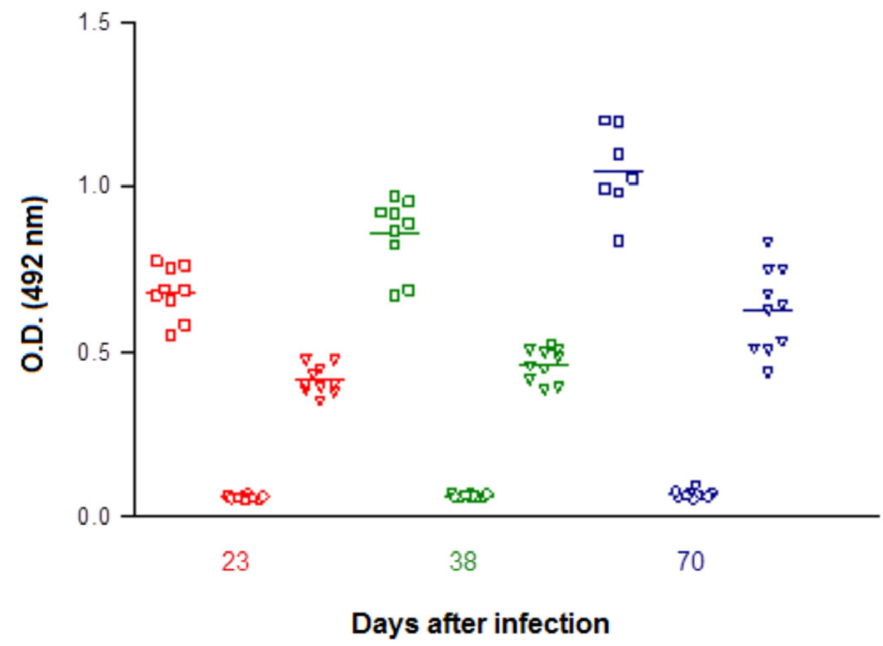

Fig. 4 - Dynamics of ELISA estimated circulating anti- T. canis Ig G antibodies in BALB/c mice infected with Toxocara canis $(\square)$, Strongyloides venezuelensis $(\bigcirc)$, and concomitantly $(\nabla)$ with both parasites. Bar represents median.

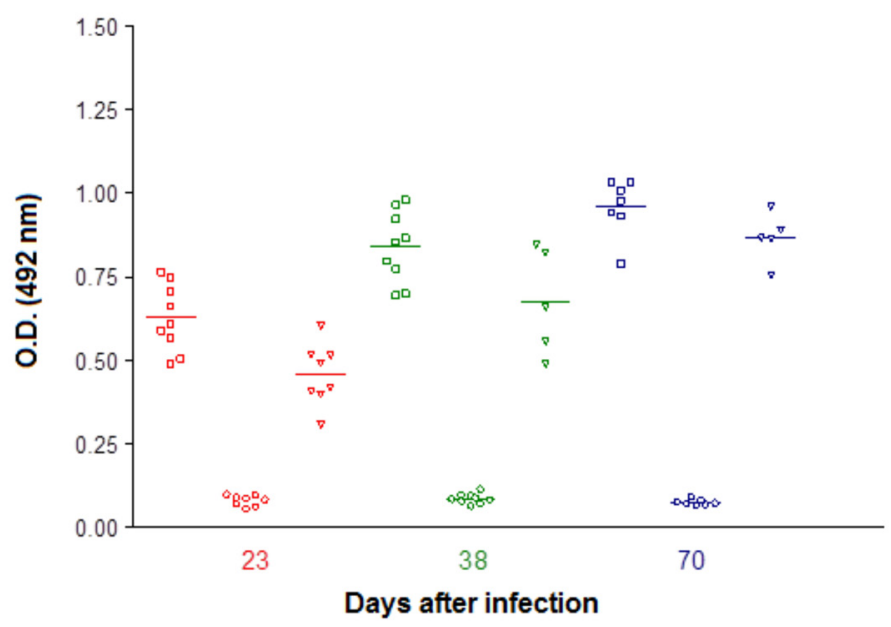

Fig. 5 - Dynamics of ELISA estimated circulating anti- T. canis Ig G antibodies in BALB/c mice infected with Toxocara canis $(\square)$, Toxoplasma gondii $(\bigcirc)$, and concomitantly $(\nabla)$ with both parasites. Bar represents median.

Western blotting results indicate that the group infected only with T. gondii was non-reactive; in the remaining mice similar patterns of reactivity in the $38^{\text {th }}$ day (Fig. 7 , tape 6 ) and $70^{\text {th }}$ p.i. (Fig. 8, strip 6) were observed, with a predominance of 97 and $66 \mathrm{kDa}$ bands.

Data on mortality after 70 days of infection (Table 2) indicate no significant difference $(p>0.05)$ among the rates of all groups.

\section{DISCUSSION}

Toxocara canis is responsible for significant morbidity in young dogs and in recent decades has also aroused great interest as a possible cause of injury to humans due to the high frequency of soil contamination with Toxocara eggs ${ }^{12,35,36}$. Since diagnosis of human infection by larvated eggs of Toxocara became available by relative safety means, toxocariasis has been considered a public health problem, being almost always diagnosed in Brazil when properly investigated ${ }^{12}$.

The objective of this study was to analyze the development of humoral immune response by $\mathrm{IgG}$ antibodies in mice subjected to experimental infection by larvae of Toxocara canis and, concurrently, to other parasites, using a model that, except for their differences, could reproduce the situation faced in natural conditions for paratenic hosts, particularly, humans. The main interest was to obtain information about the results of serological tests routinely used in the diagnosis of toxocariasis and, secondarily, to determine whether co-infection by other parasites in mice infected with $T$. canis could alter their survival rate.

Because of the difficulties in demonstrating the presence of larvae of T. canis in the tissues of humans, immunodiagnostic tests currently offer the only practical way to estimate the prevalence of human toxocariasis and had been widely used to confirm the clinical diagnosis of this disease and had also been used in seroepidemiological surveys ${ }^{32}$.

SAVIGNY et al. (1979) ${ }^{39}$, used excretory-secretory antigen (ES) produced in vitro by larvae of $T$. canis in immunoenzyme assay (ELISA), and were able to differentiate toxocariasis from other infections caused by helminths. These authors, however, worked in areas where the prevalence of human infection with intestinal parasites was very low. Even under similar conditions YANG \& KENNEDY $(1979)^{42}$ observed cross reactions between the sera of patients with infections caused by T. canis and A. lumbricoides. On the other hand, the occurrence of low specificity in serological tests for diagnosis of human toxocariasis was emphasized by LYNCH et al. $(1988)^{30}$, working in the region of Venezuela with high prevalence of human infection by several intestinal parasites. In our laboratory practice, absorption with extracts of A. lumbricoides or A. suum is required practice in the routine diagnosis of human toxocariasis ${ }^{13}$ and, in certain circumstances, absorption with antigens of Strongyloides is also recommended 5 .

In the conditions of the present experiment, no cross-reactivity was observed in ELISA tests performed in sera of mice coinfected with $T$. canis larvae and either T. crassiceps, S. mansoni, S. venezuelensis or T. gondii. However, mice infected by A. suum larvae showed cross-reactions with $T$. canis $\mathrm{ES}$ antigens in the $70^{\text {th }}$ day after infection. These results, even indicating the occurrence of cross-reactivity with Ascaris, in an unexpressive level, approach the results obtained by CUÉLLAR et al. ${ }^{14}$ who did not observe reaction against the ES antigen of T. canis in $\mathrm{BALB} / \mathrm{c}$ mice inoculated with larvated eggs of A. suum and followed for 11 weeks. On the other hand, other authors have reported the occurrence of cross reactions with ES antigen of $T$. canis when sera from mice and rabbits infected with $A$. suum were examined ${ }^{18}$, similar to findings in humans ${ }^{36}$. The comparison between the absorbance level observed in the serum of mice infected only by $T$. canis and those co-infected by T. canis and A. suum showed no significant difference in the $70^{\text {th }}$ day after infection (Fig. 1), when the peak of antibody production in mice experimentally infected by $T$. canis tends to occur ${ }^{11}$.

Our findings could be compared to those from FAN \& SU ${ }^{18}$ who observed non cross reactive IgG against Ascaris suum ES antigens (AsES) in sera of $T$. canis and A. cantonensis ICR infected mice. CUÉLLAR et $a l .{ }^{14}$ also reported that sera of BALB/c mice orally infected with $T$. canis embrionated eggs showed no cross reactions to AsES antigen. In previous study FAN \& SU ${ }^{18}$ observed no cross-reactivity to ES antigens of T. canis 
LESCANO, S.A.Z.; NAKHLE, M.C.; RIBEIRO, M.C.S.A. \& CHIEFFI, P.P. - IgG antibody responses in mice coinfected with Toxocara canis and other helminths or protozoan parasites. Rev. Inst. Med. Trop. Sao Paulo, 54(3): 145-52, 2012.

or Toxascaris leonina larvae searching IgG in sera from A. suum- and A. cantonensis- infected mice as well as serum immunoglobulin from A. suum-, T. leonina- or T. canis- infected mice as examined by ELISA, SDS-PAGE and immunofluorescence.

Western blotting analysis of IgG anti-T. canis (Fig. 7-9) did not add much to that observed by ELISA. Sera from mice infected only by $A$. suum were non-reactive, whereas those from mice concurrently infected with $T$. canis and A. suum showed similar patterns of reactivity 23 and 70 days p.i., predominantly in bands of 45 and $97 \mathrm{kDa}$ (Fig. 6, strip 2, Fig. 8, strip 2). On the $70^{\text {th }}$ day, however, the presence of a band of $66 \mathrm{kDa}$ was observed, considered responsible for possible cross-reactivity between antigens of these ascarids ${ }^{18,34}$.

Studying sera from humans infected with T. canis in Venezuela, LYNCH et al $(1988)^{30}$ found cross-reactivity between this ascarid and a large range of helminth parasites in high prevalence. The experimental model used in the present study, however, only managed to show crossreactivity in the case of infection with $A$. suum, that undoubtedly presents the closest phylogenetic relationship to the genus Toxocara ${ }^{37,41}$. It is possible, however, that this discrepancy is due to the fact that, in natural conditions, the hosts are subjected to situations that favor reinfection and that this is probably responsible for the greater stimulation of antibodies against this parasite. Another fact that deserves attention refers to the parasitic load that should eventually be greater in natural conditions, especially in the case of soil transmitted helminthic infections. With regards to mortality no significant differences among the three groups of mice were observed in the present experiment (Table 2), suggesting the absence of adverse interactions.

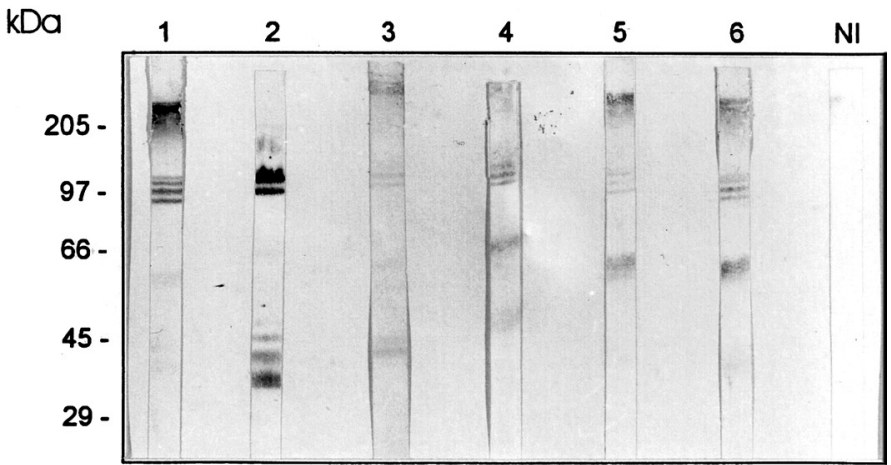

Fig. 6 - Results of Western blotting using Toxocara canis ES antigen with serum samples of mice infected with Toxocara canis (1), Ascaris suum (2), Taenia crassiceps (3), Schistosoma mansoni (4), Strongyloides venezuelensis (5) and Toxoplasma gondii (6), 23 days after infection. $\mathrm{NI}=$ non infected control.

No reactivity against $T$. canis ES antigens both in ELISA tests and Western blotting was observed in mice infected by $T$. crassiceps (fig 6-8, strip 3). However, lower levels of absorbance were found in the group concomitantly infected by $T$. canis and T. crassiceps when it was compared with the group infected only by $T$. canis, suggesting the occurrence of a possible interference of infection by cestode in the expression of the humoral immune response anti-Toxocara, analyzed at the three times (Fig. 2).

Our results suggest, as well, the occurrence of negative interactions ${ }^{7,21}$

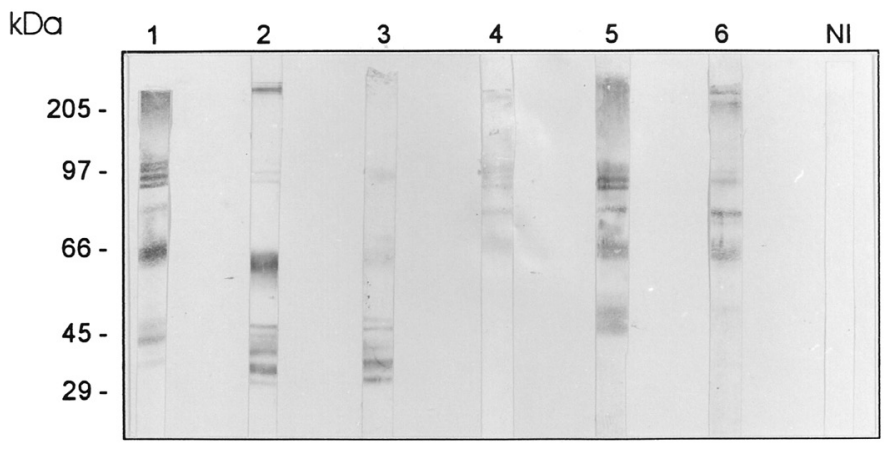

Fig. 7 - Results of Western blotting using Toxocara canis ES antigen with serum samples of mice infected with Toxocara canis (1), Ascaris suum (2), Taenia crassiceps (3), Schistosoma mansoni (4), Strongyloides venezuelensis (5) and Toxoplasma gondii (6), 38 days after infection. $\mathrm{NI}=$ non infected control.

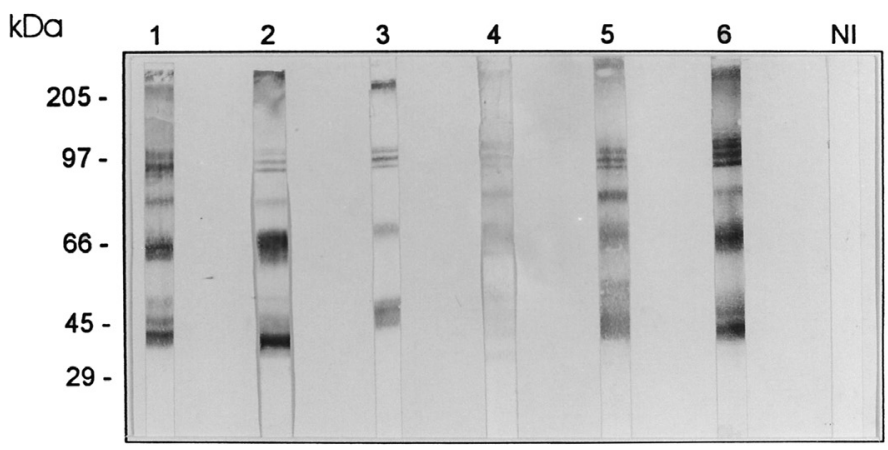

Fig. 8 - Results of Western blotting using Toxocara canis ES antigen with serum samples of mice infected with Toxocara canis (1), Ascaris suum (2), Taenia crassiceps (3), Schistosoma mansoni (4), Strongyloides venezuelensis (5) and Toxoplasma gondii (6), 70 days after infection. $\mathrm{NI}=$ non infected control.

in the concomitant infection of Toxocara and T. crassiceps, with the establishment of fewer larvae of $T$. canis in animals submitted to concomitant infection, since there seems to be parallelism between the amount of larvae present and the serological title observed in experimentally infected mice ${ }^{23}$. However, this interaction, if it occurred, did not express a significant change in the mortality rate observed (Table 2).

There are several references to the occurrence of interactions between infection with other parasites and S. mansoni, both in experimental models and in humans, showing negative or positive interactions ${ }^{8,15,19,24,27}$. In this study mice coinfected with $T$. canis - S.mansoni showed in the $23^{\text {rd }}$ and $70^{\text {th }}$ days after infection, lower production of anti-Toxocara antibodies when compared to the group infected only by the ascarid (Fig. 3). There was also a lower rate of mortality in animals co-infected or infected only by S. mansoni (Table 2), although no significant difference was found in the number of $S$. mansoni specimens recovered by portal perfusion in mice only infected with the trematode and those concurrently infected with $T$. canis.

It is possible that these results are the consequence of the interaction between the immune responses determined by both helminths. Infection by larvae of $T$. canis determines important activation of $\mathrm{T}$ cells, $\mathrm{Th} 2$ pattern, and a concomitant reduction in the number of Th1 cells ${ }^{16}$. 


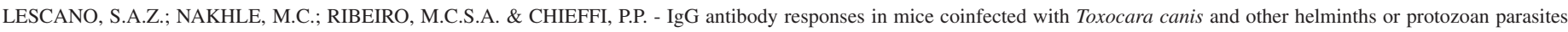
Rev. Inst. Med. Trop. Sao Paulo, 54(3): 145-52, 2012.

Infection with $S$. mansoni also favors a predominance of Th2 response, which can inhibit or modulate Th1 response ${ }^{33}$, while in mice, at least initially, a response mediated by Th1 cells should be important ${ }^{25}$.

Infection of synanthropic animals by $T$. gondii is almost as common as infection of dogs by T.canis. Both parasites are zoonotic; however, the prevalence of human infection by $T$. gondii is almost always higher than that of human toxocariasis, especially in the older age groups. On the other hand, concomitant infection by both parasites might be common in humans since the protozoan and the ascarid share soil ingestion as a common mode of exposure ${ }^{26,38}$.

There are some references to the interaction of concomitant experimental infection of $T$. gondii and other parasites, resulting sometimes in different frames than the simple addition of individual actions of each involved species ${ }^{2,17,27}$. On the other hand, CHEN et al. ${ }^{9}$ used modified ELISA rapid test to detect circulating antigens of $T$. gondii in sera of rabbits infected with this protozoan and observed no cross-reactivity with crude antigens of Cryptosporidium parvum, S. japonicum, Paragonimus sp., Brugia malayi, A. duodenale, A. lumbricoides and Trichinella spiralis, and, also, Plasmodium falciparum, the last one in human sera.

Data obtained in mice infected only by $T$. canis and in the group undergoing concomitant infection $T$. canis $-T$. gondii in this study revealed no significant differences with respect to the humoral immune response, when sera from both groups were analyzed by enzyme immunoassay (Fig. 5), except that observed in the twenty-third day of infection, when higher levels of anti-Toxocara antibodies in animals only infected with the ascarid were detected. This result suggests some delay in the genesis of humoral immune responses in coinfection T. canis - T. gondii, which did not last for long time.

The predominant immune response in toxoplasmosis depends mainly on $\mathrm{T}$ cells identified with the Th1 pattern. It is known, however, that cytokines derived from lymphocytes with a Th2 pattern (IL-4 and IL-10) have some importance in modulating the immune response in infection by $T$. gondii, suggesting the possibility of some interaction between both types of response $e^{4,40}$.

Likewise observed for co-infection between T. canis-T. crassiceps and $T$. canis-S. mansoni in the concomitant infection between T. canis-S. venezuelensis less expressive levels of anti-Toxocara antibodies were found. At the same time, a lower mortality rate was verified in mice subjected to concomitant infection.

The results of this study, although valid only for the experimental model used, suggest that, in natural conditions, concomitant parasitic infections may differentially modulate host responses. Such interactions should be considered when interpreting real situations, both in terms of animal infections and in the case of the involvement of human beings.

\section{RESUMO}

\section{Anticorpos IgG em camundongos coinfectados por Toxocara canis e outros helmintos e por protozoários parasitos}

Estudou-se a resposta imune humoral expressa por anticorpos da classe IgG em camundongos BALB/c experimentalmente infectados com
Toxocara canis em duas situações distintas. Na primeira, com o objetivo de verificar in vivo a possível reatividade cruzada entre Toxocara canis e outros parasitos (Ascaris suum, Taenia crassiceps, Schistosoma mansoni, Strongyloides venezuelensis e Toxoplasma gondii), foram realizados experimentos constituídos por três grupos de camundongos: um infectado apenas por Toxocara canis, outro com uma das demais espécies de parasitos estudados e um terceiro concomitantemente infectado por Toxocara canis e a espécie em questão. Todos os animais foram sangrados, através do plexo orbitário, 23, 38 e 70 dias após infecção. Os soros foram analisados para a presença de anticorpos anti-Toxocara por meio de teste imunoenzimático (ELISA) e por Immunoblotting, empregando-se antígeno de excreção-secreção (ES), obtido a partir da cultura de larvas de terceiro estádio de Toxocara canis. Para todos os experimentos utilizou-se grupo controle negativo constituído por 10 camundongos não infectados. Apenas no caso da infecção por Ascaris suum, nas condições experimentais observadas, logrou-se demonstrar ocorrência de reatividade cruzada com antígenos de Toxocara canis. Verificou-se, entretanto, no caso das coinfecções entre Toxocara canisSchistosoma mansoni, Toxocara canis-Strongyloides venezuelensis e Toxocara canis-Taenia crassiceps produção de anticorpos anti-Toxocara em níveis significativamente inferiores do que os encontrados nos camundongos infectados somente por Toxocara canis. Nas coinfecções com Schistosoma mansoni ou Strongyloides venezuelensis observou-se, também, menor taxa de letalidade quando comparada à ocorrida nos animais com as respectivas infecções simples.

\section{ACKNOWLEDGMENTS}

This work was supported by Coordenação de Aperfeiçoamento de Pessoal de Nível Superior - CAPES (Dr. Susana Z. Lescano).

\section{REFERENCES}

1. Anderton BH, Thorpe RC. New methods of analysing for antigens and glycoproteins in complex mixtures. Immunol Today. 1980;1:122-7.

2. Azab ME, Safar EH, Khattab HM. Concomitant Toxoplasma and Toxocara infections. J Egypt Public Health Assoc. 1990;65:253-61

3. Bach-Rizzatti BC. Desenvolvimento do teste imunoenzimático ELISA para o diagnóstico da toxocaríase humana. [dissertação]. São Paulo: Faculdade de Ciências Farmacêuticas da Universidade de São Paulo; 1984.

4. Bahia-Oliveira LMG, Silva JA, Peixoto-Rangel AL, Boechat MSB, Oliveira AMWA, Massara CL, et al. Host imune response to Toxoplasma gondii and Ascaris lumbricoides in a highly endemic area: evidence of parasite co-immunomodulation properties influencing the outcome of both infections. Mem Inst Oswaldo Cruz. 2009; 104:273-80.

5. Brito T, Chieffi PP, Peres BA, Santos RT, Gayotto LC, Vianna MR, et al. Immunohistochemical detection of toxocaral antigens in human liver biopsies. Intern J Surg Pathol. 1994;2:117-23.

6. Camparoto ML, Fulan B, Colli CM, Paludo ML, Falavigna-Guilherme AL, Fernandez MA. Initial stage of development and migratory behavior of Toxocara canis larvae in BALB/c mouse experimental model. Genet Mol Res. 2008;7:444-50.

7. Cattadori IM, Boag B, Hudson PJ. Parasite co-infection and interaction as drivers of host heterogeneity. Int J Parasitol. 2008;38:371-80.

8. Chamone M, Marques CA, Atuncar GS, Pereira AL, Pereira LH. Are there interactions between schistosomes and intestinal nematodes? Trans R Soc Trop Med Hyg. 1990;84: $557-8$. 
LESCANO, S.A.Z.; NAKHLE, M.C.; RIBEIRO, M.C.S.A. \& CHIEFFI, P.P. - IgG antibody responses in mice coinfected with Toxocara canis and other helminths or protozoan parasites. Rev. Inst. Med. Trop. Sao Paulo, 54(3): 145-52, 2012.

9. Chen R, Lu S, Lou D, Lin A, Zeng X, Ding Z, et al. Evaluation of a rapid ELISA technique for detection of circulating antigens of Toxoplasma gondii. Microbiol Immunol. $2008 ; 52: 180-7$

10. Chieffi PP, Del Guercio VM, Ueda M, Mello LB. Importância de Rattus norvegicus capturados no município de São Paulo, SP, Brasil, como hospedeiros paratênicos de Toxocara canis (Ascaroidea, Nematoda). Rev Inst Adolfo Lutz. 1981;41:89-91.

11. Chieffi PP, Peres BA, Mello EO, Kanamura H, Brandão M. Persistence of specific antibody response in different experimental infections of mice with Toxocara canis larvae. Rev Inst Med Trop São Paulo. 1995;37:187-90.

12. Chieffi PP, Santos SV, Queiroz ML, Lescano SA. Human toxocariasis: contribution by Brazilian researchers. Rev Inst Med Trop São Paulo. 2009;51:301-308.

13. Chieffi PP, Ueda M, Camargo ED, Souza AM, Guedes ML, Gerbi LJ, et al. Visceral larva migrans: a seroepidemiological survey in five Municipalities of São Paulo State, Brazil. Rev Inst Med Trop São Paulo. 1990;32: 204-10.

14. Cuéllar C, Fenoy S, Guillén J. Cross-reactions of sera from Toxascaris leonina and Ascaris suum infected mice with Toxocara canis, Toxascaris leonina and Ascaris suum antigens. Int J Parasitol. 1995;25:731-9.

15. Curry AJ, Else KJ, Jones F, Bancroft A, Grencis RK, Dunne, DW. Evidence that cytokinemediated immune interactions induced by Schistosoma mansoni alter disease outcome in mice concurrently infected with Trichuris muris. J Exp Med. 1995;181:769-74.

16. De Carli M, Romagnani, S, Del Prete GF. Human T-cell response to excretory-secretory antigens of Toxocara canis. A model of preferential "in vitro" and "in vivo" activation of Th2 cells. In: Lewis JW \& Maizels RM, Editors. Toxocara and Toxocariasis. Clinical, epidemiological and molecular perspectives. Bedforshire: British Society for Parasitology with the Institute of Biology; 1993. p. 125-32.

17. Dubey JP. Induced Toxoplasma gondii, Toxocara canis, and Isospora canis infections in coyotes. J Am Vet Med Assoc. 1982;181:1268-9

18. Fan CK, Su KE. Cross-reactions with Ascaris suum antigens of sera from mice infected with A. suum, Toxocara canis, and Angiostrongylus cantonensis. Parasitol Int. 2004;53:263-71.

19. Grieve RB, Stewart VA, Parsons JC. Immunobiology of larval toxocariasis (Toxocara canis): a summary of recent research. In: Lewis JW, Maizels RM. Toxocara and Toxocariasis. Clinical, epidemiological and molecular perspectives. Bedforshire: British Society of Parasitology; 1993. p. 117-124,

20. Guillen-Llera J, Bardon Iglesias R, Dominguez López P, Cuéllar Del Hoyo C. Migración larvaria de Toxocara canis y respuesta eosinofílica en las cepas murinas BALB/c y C57BL/10. Rev Ibér Parasitol. 1990;50:289-99.

21. Halvörsen O. Negative interaction amongst parasites. In: Kennedy CR. Ecological aspects of Parasitology. Amsterdam; 1976. p. 99-114.

22. Harris N, Gause WC. To B or not to B: B cells and the Th2-type immune response to helminthes. Trends Immunol. 2011:32:80-8.

23. Havasiová-Reiterová K, Tomasovicová O, Dubinsky P. Effect of various doses of infective Toxocara canis and Toxocara cati eggs on the humoral response and distribution of larvae in mice. Parasitol Res. 1995;81:13-7.

24. Higgins-Opitz SB, Dethman CD, Dingle CE, Anderson CB, Becker PJ. Intestinal parasites of conventionally maintained BALB/c mice and Mastomys coucha and the effects of a concomitant schistosome infection. Lab Anim. 1990;24:246-52.

25. James SL, Sher A. Cell-mediated immune response to schistosomiasis. Curr Top Microbiol Immunol. 1990;155:21-31.

26. Jones JL, Kruszon-Moran D, Won K, Wilson M, Schantz PM. Toxoplasma gondii and Toxocara spp. co-infection. Am J Trop Med Hyg. 2008;78:35-9.
27. Kloetzel K, Chieffi PP, Faleiros JJ, Merluzzi Filho TJ. Mortality and other parameters of concomitant infections in albino mice: the Schistosoma - Toxoplasma model. Trop Geogr Med. 1977;29:407-10.

28. Kolbaum J, Ritter U, Zimara N, Brewig N, Eschbach ML, Breloer M. Efficient control of Leishmania and Strongyloides despite partial suppression of nematode-induced Th2 response in co-infected mice. Parasite Immunol. 2011;33:226-35.

29. Lowry OH, Rosebrough NJ, Farr AL, Randall RJ. Protein measurement with the folin phenol reagent. J Biol Chem. 1951;193:265-75.

30. Lynch NR, Eddy K, Hodgen AN, Lopez RI, Turner KJ. Seroprevalence of Toxocara canis infection in tropical Venezuela. Trans R Soc Trop Med Hyg. 1988;82:275-81.

31. Lynch NR, Hagel I, Vargas V, Rotundo A, Varela M, Di Prisco MC, et al. Comparable seropositivity for ascariasis and toxocariasis in tropical slum children. Parasitol Res. 1993;79:547-50.

32. Magnaval JF, Glickman LT, Dorchies P, Morassin B. Highlights in human toxocariasis Korean J Parasitol. 2001;39:1-11.

33. Naus CW, Jones FM, Satti MZ, Joseph S, Riley EM, Kimani G, et al. Serological response among individuals in areas where both schistosomiasis and malaria are endemic: cross-reactivity between Schistosoma mansoni and Plasmodium falciparum. J Infect Dis. 2003;187:1272-82.

34. Nunes CM, Tundisi RN, Garcia JF, Heinemann MB, Ogassawara S, RIchtzenhain LJ. Cross-reactions between Toxocara canis and Ascaris suum in the diagnosis of visceral larva migrans by Western blotting technique. Rev Inst Med Trop Sao Paulo. 1997;39:253-6

35. Overgaauw PA. Aspects of Toxocara epidemiology: human toxocarosis. Crit Rev Microbiol. 1997;23:215-31.

36. Queiroz ML, Simonsen M, Paschoalotti MA, Chieffi PP. Frequency of soil contamination by Toxocara canis eggs in the South region of São Paulo municipality (SP, Brazil) in a 18 month period. Rev Inst Med Trop Sao Paulo. 2006;48:317-9.

37. Romasanta A, Romero JL, Arias M, Sánchez-Andrade R, López C, Suárez JL, et al Diagnosis of parasitic zoonoses by immunoenzymatic assays - analysis of crossreactivity among the excretory/secretory antigens of Fasciola hepatica, Toxocara canis and Ascaris suum. Immunol Invest. 2003;32:131-42.

38. Safar EH, Abd-El Ghaffar FM, Saffar SA, Makled KM, Habib KS, El Abiad R, et al. Incidence of Toxoplasma and Toxocara antibodies among out-patients in the Ophthalmic Research Institute, Egypt. J Egypt Soc Parasitol. 1995;25:839-52.

39. Savigny DH, Voller A, Woodruff W. Toxocariasis: serological diagnosis by enzyme immunoassay. J Clin Pathol. 1979;32:284-8.

40. Sher A, Gazzinelli RT, Oswaldo IP, Clerici M, Kullberg M, Pearce EJ, et al. Role of T-cell derived cytokines in the downregulation of immune responses in parasitic and retroviral infection. Immunol Rev. 1992;127:183-204.

41. Smith HV, Quinn R, Bruce R, Girdwood RW. Development of the serological response in rabbits infected with Toxocara canis and Toxascaris leonina. Trans R Soc Trop Med Hyg. 1982;76:89-94.

42. Yang J, Kennedy MT. Value of ELISA in the detection of visceral larva migrans (VLM). Can J Public Health. 1979;70:58.

Received: 3 October 2011

Accepted: 26 March 2012 